\title{
RANCANG BANGUN ABSENSI ELEKTRONIK BERBASIS MIKROKONTROLLER ATMEGA328
}

\author{
Subandi Saputra ${ }^{1^{*}}$, Aswardi ${ }^{1}$ \\ ${ }^{1}$ Program Studi Teknik Elektro Industri, FT, Universitas Negeri Padang \\ ${ }^{*}$ Coresponding author, e-mail: subandi.neutronboy95@gmail.com
}

\begin{abstract}
Abstrak- Artikel ini bertujuan untuk memperbarui sistem absensi konvensional. Fokus pembuatan Tugas Akhir ini adalah: (1)Membuat mesin absensi elektronik dengan sensor biometrik berbasiskan Mikrokontroller Atmega328, (2) Memperbaharui metode absensi konvensional menjadi absensi digital, dan (3) Menentukan kinerja karyawan berdasarkan absensi . Dalam pembuatan tugas akhir ini penulis menggunakan mikrokontroller atmega328 sebagai pusat pengontrolan utama, sensor pembaca sidik jari sebagai input utama, led sebagai penampil informasi waktu pada rangkaian real time clock, dan rangkaian sdcard module sebagai sistem basis data yang digunakan untuk menyimpan informasi pada saat absensi dilakukan. Berdasarkan hasil pengujian rancang bangun absensi elektronik berbasis mikrokontroller atmega328 adalah sebagai berikut, pertama alat ini dapat digunakan sebagai pengganti sistem pengambilan absensi secara konvensional. Hal ini disebabkan karena alat ini dilengkapi dengan sensor pembaca sisik jari sehingga dalam pengambilan absensi tidak dapat diwakilkan. Selain itu, alat ini juga telah dilengkapi dengan RTC sebagai sistem pengatur waktu yang akan mencatat keterlambatan setiap user pada alat ini. kedua proses pengambilan absensi (resensi) hanya dapat dilakukan setelah pengguna melakukan proses registrasi.
\end{abstract}

Kata kunci : absensi, elektronik, atmega328, biometrik, sidik jari.

Abstract-This paper aims to update the conventional attendance system. The focus of this final assignment is: (1) Creating an electronic attendance machine with biometric sensor based on Microcontroller Atmega328, (2) Renewing conventional attendance method into digital absence, and (3) Determining employee performance based on absenteeism. In making of this final task, the writer uses microcontroller atmega328 as main control center, fingerprint reader as main input, LCD as time information viewer on real time clock circuit, and series of SD card module as database system used to store information at the time of absences. Based on the results of the testing of the design of electronic attendance based on atmega328 microcontroller is as follows, the first can be used as a substitute for conventional absorption taking system. This is because the tool is equipped with fingerprint reader sensor so that in absenteeism cannot be represented. In addition, this tool also has been equipped with RTC as a timer system that will record the delay of each user on this tool. the second process of taking attendance (reviewer) can only be done after the user perform the registration process.

Keywords: Attendance, Electronics, Atmega328, Biometrics, Fingerprint

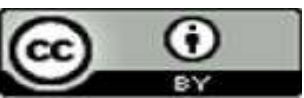

This is an open access article distributed under the Creative Commons 4.0 Attribution License, which permits unrestricted use, distribution, and reproduction in any medium, provided the original work is properly cited. (C2018 by Author and Universitas Negeri Padang

\section{PENDAHULUAN}

Absensi merupakan daftar pola kebiasaan ketidakhadiran dari tugas atau kewajiban sedangkan berdasarkan kamus Bahasa Indonesia, absen adalah tidak bekerjanya seorang pegawai pada saat hari kerja, karena sakit, izin, alpa atau cuti. Absensi adalah daftar administrasi ketidakhadiran pegawai [1]. Absensi memiliki fungsi yang sangat penting dalam dunia pekerjaan salah satunya yaitu untuk menilai tingkat kerajinan pegawai berdasarkan banyak atau sedikitnya seorang pegawai dalam mengambil cuti. Selain itu absensi juga berfungsi untuk mengetahui jam masuk atau hari kerja pegawai.

Dewasa ini terdapat berbagai macam cara pengambilan absensi, di antaranya yaitu dengan menggunakan kertas dan tandatangan atau disebut sebagai absensi konvensional. Adapun kelemahannya tandatangan dapat dengan mudah dipalsukan, data mudah hilang dikarenakan tidak adanya sistem backup. Selain itu terdapat pengambilan absensi dengan menggunakan kartu identitas cara ini sudah dapat dibilang lebih maju jika dibandingkan dengan absensi konvensional Selain itu absensi ini juga sudah memiliki sistem penyimpanan sendiri. Walaupun demikian proses absensi dengan menggunakan sistem absensi 
tersebut tidak dapat dilakukan jika kartu identitas hilang atau tertinggal. Berkaitan dengan keadaan demikian, maka dikembangkan sebuah mesin absensi digital dengan menggunakan sensor biometrik yang berfungsi sebagai pengganti kartu identitas serta tanda tangan untuk melakukan proses absensi dalam metode absensi. Untuk itu dibuatlah sebuah tulisan dengan judul rancang bangun absensi elektronik dengan sensor fingerprints berbasis Mikrokontroller Atmega328.

Pencatatan kehadiran sering dikenal dengan absensi. Ketidakhadiran (absenteism) adalah kegagalan untuk melapor pada waktu kerja [2]. Dengan kata lain ketidakhadiran merupakan kegagalan seorang karyawan untuk hadir di tempat kerja pada hari kerja. Ketidakhadiran berbeda dengan terlambat ( latenes) yang menunjukkan kegagalan untuk datang tepat waktu. Cara menghitung ketidakhadiran dengan membagi time lose yaitu jumlah hari-hari yang hilang dengan frekuensi yaitu jumlah ketidakhadiran selam satu periode.

Absensi merupakan kegagalan pekerja pegawai untuk melaporkan pekerjaan ketika mereka di jadwalkan bekerja [3]. Sedangkan Absensi adalah suatu kegiatan atau rutinitas yang dilakukan oleh karyawan untuk membuktikan dirinya hadir atau tidak hadir dalam bekerja di suatu perusahaan [4].

Berdasarkan metodenya absensi dapat dibedakan menjadi :

1. Sistem absensi konvensional

Sistem konvensional adalah sebuah sistem absensi yang mana dalam pengambilan data dan penyimpanannya menggunakan secarik kertas, yang mana menjadikan sistem absensi ini menjadi sistem absensi yang memiliki banyak kekurangan yaitu sistem absensi ini mudah hilang karena belum terdapatnya media penyimpanan dalam bentuk digital sehingga absensi ini juga mudah dicurangi dengan cara memalsukan tandatangan para pegawai yang mengambil cuti.

2. Sistem absensi dengan menggunakan kartu identitas

Sistem absensi dengan menggunakan kartu identitas adalah sebuah sistem absensi yang metode pengambilan datanya menggunakan kartu identitas dari para pemegang kartu tersebut, sistem absensi ini biasanya menggunakan pemindai kode bar. Kode bar yang dimaksud di sini yaitu kode atau karakter yang mewakili nomor identitas, yang dilengkapi dengan sebuah infrared sebagai pemindainya dan telah dilengkap media penyimpanan data untuk disimpan pada database dari sistem absensi tersebut. Sehingga menjadikan absensi tersebut tidak mudah kehilangan data-data pentingnya. Sistem absensi tersebut murah akan tetapi memiliki kelemahan yaitu para pemilik kartu identitas akan menitipkan absensinya kepada temannya yang hadir di samping itu jika kartu identitas tidak terbawa atau hilang maka pemilik kartu tidak bisa melakukan proses absensi pada hari tersebut.

3. Sistem absensi dengan menggunakan pemindai hidup

Sistem absensi dengan menggunakan pemindai hidup (biometrics) adalah sebuah pembaruan dari semua sistem absensi. Hal ini disebabkan karena dalam pengambilan data sistem ini sudah dilengkapi pemindai hidup. Dalam pembuatan tulisan ini digunakan pemindai sidik jari (fingerprints), dengan menggunakan metode pengambilan data yang dilengkapi pemindai sidik jari manusia. Sistem absensi ini memiliki sebuah alat elektronik yang akan memindai sidik jari yang disebut pemindai hidup(biometrics) yang kemudian akan memprosesnya ke dalam bentuk digital menggunakan metode pemrosesan citra digital. Dengan sistem absensi ini pegawai tidak memerlukan kartu untuk dibawa ke mana-mana sehingga pegawai tidak perlu khawatir terhadap tertinggalnya kartu identitas yang dimilikinya. Namun sistem absensi ini lebih mahal jika dibandingkan dengan sistem absensi konvensional dan sistem absensi dengan menggunakan kartu identitas, dikarenakan sistem absensi ini menggunakan sidik jari maka yang sering terjadi adalah tidak terbacanya sidik jari dikarenakan sidik jari basah atau tergores oleh karena itu dalam tulisan ini disarankan untuk memakai sidik jari jempol kiri karena tangan kiri lebih dominan untuk tidak digunakan jika dibandingkan dengan tangan kanan sehingga tangan kiri akan bisa lebih terhindar dari goresan karena kecelakaan.

\section{STUDI PUSTAKA}

\section{A. Mikrokontroller Atmega328}

Mikrokontroller dapat dikatakan sebuah sistem komputer yang seluruh atau sebagian besar elemennya dikemas dalam satu chip sehingga sering disebut sebagai single chip mikrokomputer. Tidak seperti sistem komputer yang mampu menangani berbagai macam program aplikasi, mikrokontroller hanya dapat digunakan untuk suatu aplikasi saja. Mikrokontroller dapat dikatakan sebuah sistem komputer yang seluruh atau sebagian Beberapa tahun terakhir, mikrokontroller sangat banyak digunakan terutama dalam pengontrolan robot. Seiring 
perkembangan elektronika, mikrokontroller dibuat semakin kompak dengan bahasa pemrograman yang juga ikut berubah. Salah satunya adalah mikrokontroller AVR (Alf and Vegard's Risc processor) ATmega328 yang menggunakan teknologi RISC (Reduce Instruction Set Computing) di mana program berjalan lebih cepat karena hanya membutuhkan satu siklus clock untuk mengeksekusi satu instruksi program. Secara umum, AVR dapat dikelompokkan menjadi 4 kelas, yaitu kelas ATtiny, keluarga AT90Sxx, keluarga ATmega, dan AT86RFxx. Pada dasarnya yang membedakan masing-masing kelas adalah memori, peripheral, dan fungsinya. Dari segi arsitektur dan instruksi yang digunakan, mereka bisa dikatakan hampir sama.

ATmega328 adalah chip mikrokontroller 8-bit berbasis AVR-RISC buatan Atmel. Chip ini memiliki $32 \mathrm{~KB}$ memori ISP flash dengan kemampuan baca-tulis (read write), $1 \mathrm{~KB}$ EEPROM, dan 2 KB SRAM. Dari kapasitas memori Flash nya yang sebesar $32 \mathrm{~KB}$ itulah chip ini diberi nama ATmega328. Chip lain yang memiliki memori $8 \mathrm{~KB}$ diberi nama ATmega8, dan ATmega16 untuk yang memiliki memori 16 KB.

1. Fitur Atmega328

RISC (Reduce Instruction Set Computer) adalah arsitektur dari atmega328, yang mana setiap proses eksekusi data lebih cepat dari pada arsitektur CISC (Completed Instruction Set Computer). Mikrokontroller ini memiliki beberapa fitur antara lain:

a. Memiliki EEPROM (Electrically Erasable Programmable Read Only Memory) sebesar $1 \mathrm{~KB}$ sebagai tempat penyimpanan data semi permanen karena EEPROM tetap dapat menyimpan data meskipun catu daya dimatikan

b. Memiliki SRAM (Static Random Access Memory) sebesar 2KB.

c. Memiliki pin I/O digital sebanyak 14 pin 6 diantaranya PWM (Pulse Width Modulation) output.

d. $32 \times 8$-bit register serba guna.

e. Dengan clock $16 \mathrm{MHz}$ kecepatan mencapai 16 MIPS.

f. 32 KB Flash memory dan pada mikrokontroller atmega328 memiliki bootloader yang menggunakan $2 \mathrm{~KB}$ dari flash memori sebagai bootloader.

g. 130 macam instruksi yang hampir semuanya dieksekusi dalam satu siklus clock.

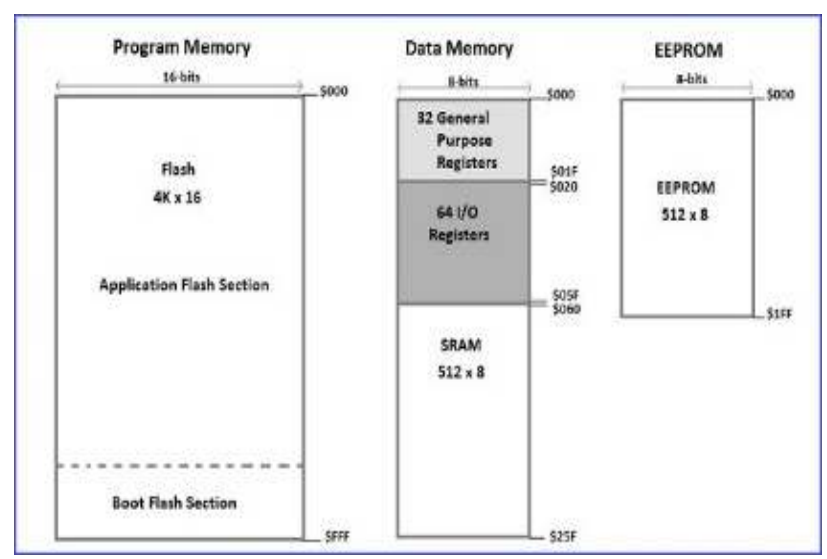

Gambar 1 memori mapping atmega328 [5]

2. Catu Daya Mikrokontroller Atmega328

Mikrokontroller Atmega328 dapat diaktifkan melalui koneksi USB atau dengan catu daya eksternal. Sumber daya dipilih secara otomatis. Untuk sumber daya Eksternal (non-USB) dapat berasal baik dari adaptor AC-DC atau baterai. Adaptor ini dapat dihubungkan dengan memasukkan $2.1 \mathrm{~mm}$ jack DC ke soket listrik board. Baterai dapat dimasukkan pada pin header Gnd dan Vin dari konektor DAYA.

Board dapat beroperasi pada pasokan eksternal dari 6 sampai 20 volt. Jika menggunakan tegangan kurang dari 6 volt tidak akan stabil. Jika menggunakan lebih dari $12 \mathrm{~V}$, regulator tegangan bisa panas dan merusak papan. Rentang yang dianjurkan adalah 7 sampai 12 volt.

Pin listrik yang tersedia adalah sebagai berikut:

a. VIN merupakan input tegangan ke board mikrokontroller atmega328, pin tersebut dapat digunakan sebagai pemasok daya dari steker listrik.

b. $5 \mathrm{~V}$ merupakan pin output $5 \mathrm{~V}$ yang telah diatur oleh regulator papan mikrokontroller atmega328. Board dapat diaktifkan dengan daya yang berasal dari steker listrik DC (7 $12 \mathrm{~V})$, konektor USB (5V), atau pin VIN board (7-12V).

c. GND pin Ground.

d. IOREF merupakan pin yang akan memberikan tegangan referensi pada papan mikrokontroller atmega328 ketika mikrokontroller beroperasi.

B. Sensor Sidik jari

Sensor merupakan salah satu bentuk perangkat keras yang digunakan untuk menangkap suatu perubahan lingkungan yang terjadi di sekitar sensor seperti objek, suhu, cahaya, suara, tekanan, dan sebagainya. Sensor dapat berperan sebagai indra jika diintegrasikan pada suatu rangkaian 
elektronik. Salah satunya seperti sidik jari yang merupakan sebagian dari teknologi biometrika

Sifat yang dimiliki oleh sidik jari antara lain Perennial nature, yaitu guratan-guratan pada sidik jari yang melekat pada kulit manusia seumur hidup, Immutability, yaitu sidik jari seseorang tidak pernah berubah, kecuali mendapatkan kecelakaan yang serius, dan Individuality, pola sidik jari adalah unik dan berbeda untuk setiap orang. Ciri khas sidik jari yang digunakan adalah guratan sidik jari yang dapat diidentifikasi dengan cara menganalisis detail dari guratan-guratan sidik jari yang dinamakan dengan "minutiae".

1. Pengelompokan sidik jari

Secara umum sidik jari dibagi menjadi 3 tipe pola utama, yaitu arch, loops, dan whorls. Selain ini hanyalah variasi dari kombinasi ketiga pola ini. Tipe loops merupakan pola yang paling banyak ditemukan pada manusia. Sekitar $60 \%$ sidik jari bertipe loops, $30 \%$ bertipe whorls, dan $10 \%$ bertipe arch.

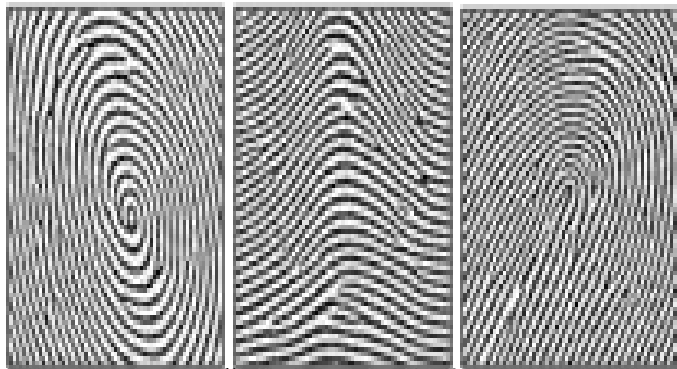

Gambar 2 Pola sidik jari Whorl Arch Loop [6]

2. Klasifikasi sidik jari

Klasifikasi sidik jari digunakan untuk mengelompokkan sidik jari ke dalam tiga kelas yang ditentukan. Kelas-kelas tersebut adalah Arch, Loop, dan Whorl. Fungsi dari pengelompokan ini adalah untuk memperkecil proses pencocokan minutia pada data dalam skala besar. Klasifikasi dilakukan dengan tiga tahap, yaitu Tahap preprosessing, yang terdiri dari segmentasi, dan Image Enhancement, Tahap ekstraksi, yang terdiri dari Ridgevalley Orientation, dan Registration dengan menggunakan algoritma R92, dan Tahap klasifikasi, algoritma klasifikasi sidik jari ini

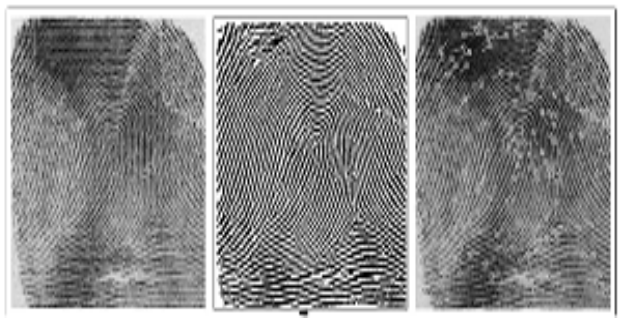

Gambar 3 Proses identifikasi minutia [6] menggunakan Probabilitic Neural Network Multi-layer, Perceptron Neural Network, dan Pseudo-ridge Tracer. Berikut adalah hasil proses dari beberapa tahap klasifikasi :

3. Pengenalan Pola

Pola adalah entitas yang terdefinisi dan dapat diidentifikasi melalui ciri-cirinya. Ciriciri tersebut digunakan untuk membedakan suatu pola dengan pola lainnya. Ciri yang bagus adalah ciri yang memiliki daya pembeda yang tinggi, sehingga pengelompokan pola berdasarkan ciri yang dimiliki dapat dilakukan dengan keakuratan yang tinggi.

Identifikasi sidik jari dilakukan untuk mencari letak minutia pada citra sidik jari. Minutia adalah sebuah karakteristik sidik jari yang banyak ditemukan pada sidik jari. Pada dasarnya minutia ada dua macam, yaitu percabangan garis (bifurcation), dan garis buntu (Ridge ending). Pada proses identifikasi, minutia-minutia ini akan dicatat lokasinya berdasarkan koordinat $(\mathrm{x}, \mathrm{y})$ dan sudut yang membentuk minutia tersebut (theta). Proses identifikasi ini dilakukan melalui beberapa tahap, seperti, menggenerate image quality maps, binarisasi image, deteksi minutia, dan Count Nighbour Ridges. Hasil dari ekstraksi minutia ini, digunakan untuk proses matching antara sidik jari penguji dengan sidik jari yang diuji. Proses matching dengan menggunakan algoritma Bozorth3 yang dikembangkan oleh Allan S. Bozorth. Algoritma ini menggunakan proses mathcing untuk lokasi $(\mathrm{x}, \mathrm{y})$ dan sudut orientasi (theta). Pada dasarnya algoritma ini menggunakan beberapa proses seperti, Construct Intra-Fingerprint Minutia Comparison Tables, Constructan InterFingerprint Compatibility Table dan Traverse the Inter Fingerprint Compatibility Table. Hasil dari beberapa prosesnya dapat dilihat pada gambar berikut:

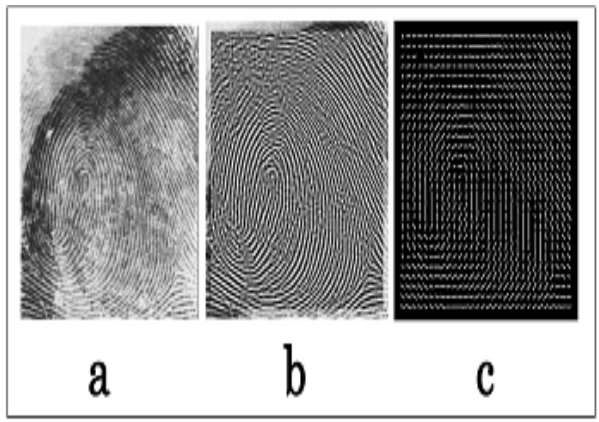

Gambar 4 Proses Klarifikasi [6]

a) Hasil segmentasi

b) Hasil image enchanments

c) Hasil ridge-valley Orientation 
Identifikasi sidik jari dilakukan untuk mencari letak minutia pada citra sidik jari. Minutia adalah sebuah karakteristik sidik jari yang banyak ditemukan pada sidik jari. Pada dasarnya minutia ada dua macam, yaitu percabangan garis (bifurcation), dan garis buntu (Ridge ending). Pada proses identifikasi, minutia-minutia ini akan dicatat lokasinya berdasarkan koordinat $(\mathrm{x}, \mathrm{y})$ dan sudut yang membentuk minutia tersebut (theta). Proses identifikasi ini dilakukan melalui beberapa tahap, seperti, menggenerate image quality maps, binarisasi image, deteksi minutia, dan Count Nighbour Ridges.

Hasil dari ekstraksi minutia ini, digunakan untuk proses matching antara sidik jari penguji dengan sidik jari yang diuji. Proses matching dengan menggunakan algoritma Bozorth3 yang dikembangkan oleh Allan S. Bozorth Algoritma ini menggunakan proses mathcing untuk lokasi $(\mathrm{x}, \mathrm{y})$ dan sudut orientasi (theta). Pada dasarnya algoritma ini menggunakan beberapa proses seperti, Construct IntraFingerprint Minutia Comparison Tables, Constructan Inter-Fingerprint Compatibility Table dan Traverse the Inter-Fingerprint Compatibility Table

4. Fingerprint Recognition

Sebuah sistem fingerprint scanner memiliki dua pekerjaan, yakni mengambil gambar sidik jari, dan memutuskan apakah pola alur sidik jari dari gambar yang diambil sama dengan pola alur sidik jari yang ada pada database. Ada beberapa cara untuk mengambil gambar sidik jari seseorang, namun salah satu metode yang paling banyak digunakan saat ini adalah optical scanning.

Inti dari scanner optical adalah charge coupled device (CCD), sistem sensor cahaya yang sama digunakan pada kamera digital dan camcorder. CCD merupakan diode peka cahaya yang disebut photosite, yang menghasilkan sinyal elektrik yang memberikan respons foton cahaya. Setiap photosite merekam sebuah pixel, titik kecil yang merepresentasikan cahaya dan membentuknya. Pixel-pixel ini membentuk pola terang dan gelap dari sebuah gambar hasil scan sidik jari seseorang. Pola terang dihasilkan oleh valley dan pola gelap dihasilkan oleh ridge.

5. Modul fingerprints ZFM60XSA

Modul fingerprints ZFM60XSA merupakan sensor sidik jari optikal, yang dapat mendeteksi sidik jadi dengan verifikasi yang sangat sederhana. Modul sensor ini bekerja dengan otak utama berupa chip DSP yang melakukan image rendering, kemudian melakukan kalkulasi, feature-finding dan terakhir searching pada data yang sudah ada.

\section{METODE PERANCANGAN}

Sistem pengambilan absensi ini menggunakan rangkaian kontrol dan pemrograman mikrokontroller Arduino sebagai pusat pengolah data yang di dapat melalui sensor pembaca sidik jari.

\section{A. Blok Diagram}

Alur dari rancangan yang akan dibuat digambarkan dalam bentuk blok diagram yang ditunjukkan pada gambar 5 .

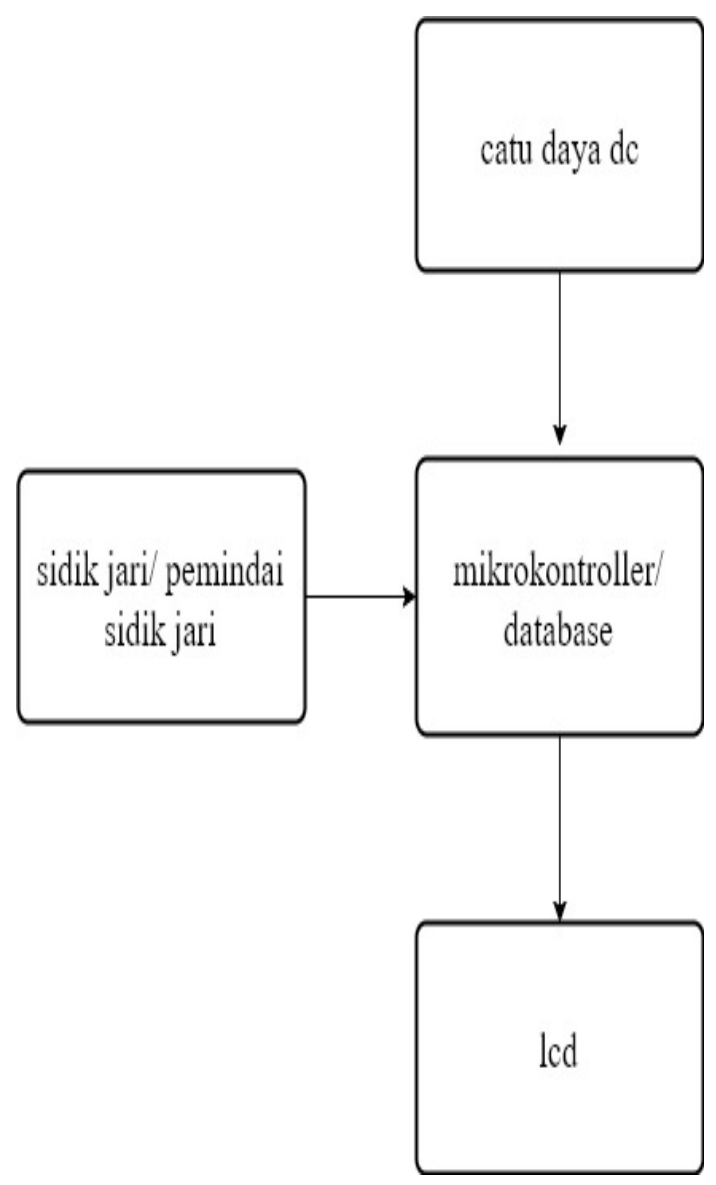

Gambar 5 Blok diagram

Adapun penjelasan masing-masing dari blok diagram di atas adalah sebagai berikut

1. Blok input pada perancangan alat ini adalah sidik jari dan pemindai sidik jari

2. Blok catu daya pada perancangan alat ini adalah catu daya de 5 volt untuk memberikan catu daya pada blok input dan 12 volt untuk catu daya pada blok kontrol. 
3. Blok kontrol pada perancangan alat ini adalah mikrokontroller atmega328 yang sekaligus berfungsi sebagai database.

4. Blok output pada alat ini adalah LCD

Adapun penjelasan masing-masing dari blok diagram di atas adalah sebagai berikut

5. Blok input pada perancangan alat ini adalah sidik jari dan pemindai sidik jari

6. Blok catu daya pada perancangan alat ini adalah catu daya dc 5 volt untuk memberikan catu daya pada blok input dan 12 volt untuk catu daya pada blok kontrol.

7. Blok kontrol pada perancangan alat ini adalah mikrokontroller atmega328 yang sekaligus berfungsi sebagai database.

8. Blok output pada alat ini adalah LCD

Prinsip Kerja Alat

1. Pendaftaran

Saat alat diaktifkan dengan menekan tombol ok maka alat siap untuk memulai proses pendaftaran(enrolll), Pilih nomor Id dengan cara tekan tombol panah ke atas atau ke bawah lalu tekan tombol ok untuk mengkonfirmasi. scan sidik jari yang mau didaftarkan ke sensor sidik jari dengan memperhatikan lampu LED yang bewarna hijau, lepas dan scan kembali sidik jari yang ingin didaftarkan.

2. Verifikasi

Dengan menekan tombol start setelah sensor siap untuk digunakan dengan memperhatikan indikator lampu hijau, maka user meletakkan jari pada permukaan sensor (pastikan jari yang diletakkan sama dengan jari di saat registrasi ) Citra Sidik jari yang diambil dibandingkan dengan basis data yang ada. Bila data pada proses verifikasi sama dengan data yang ada pada basis data maka proses presensi akan dilanjutkan dengan menampilkan nomor user pada LCD. Namun bila data pada proses verifikasi tidak sama dengan data yang ada pada basis data maka proses akan ditolak dan user harus mendaftarkan jari atau mensccankan jari yang telah didaftarkan sebelumnya.

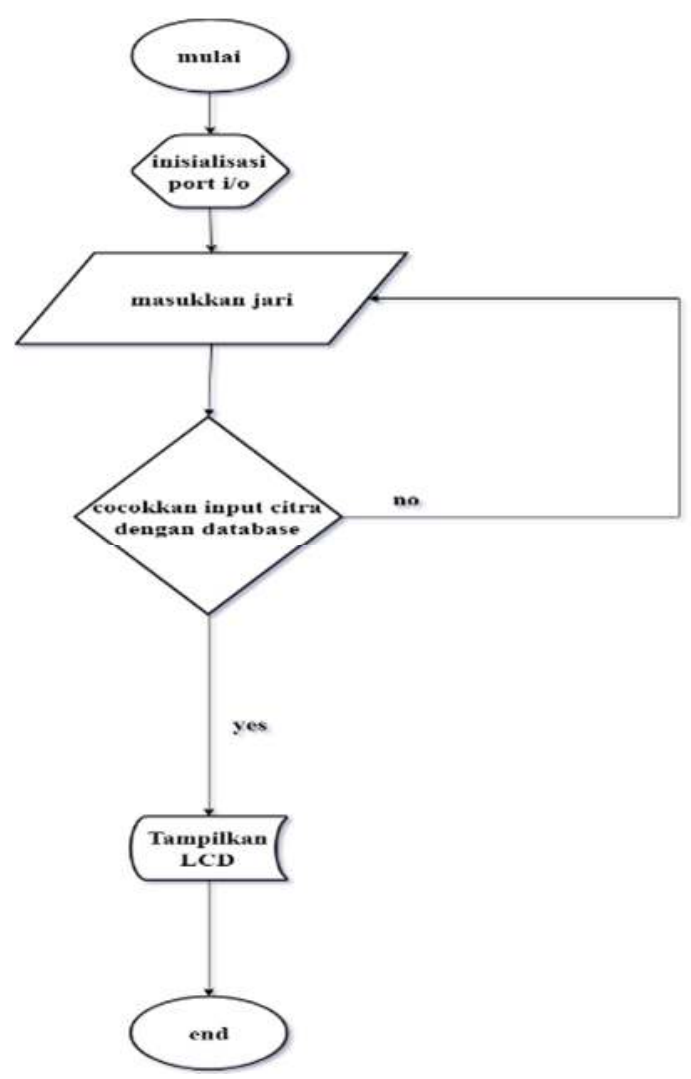

Gambar 6 diagram alir proses pendaftaran

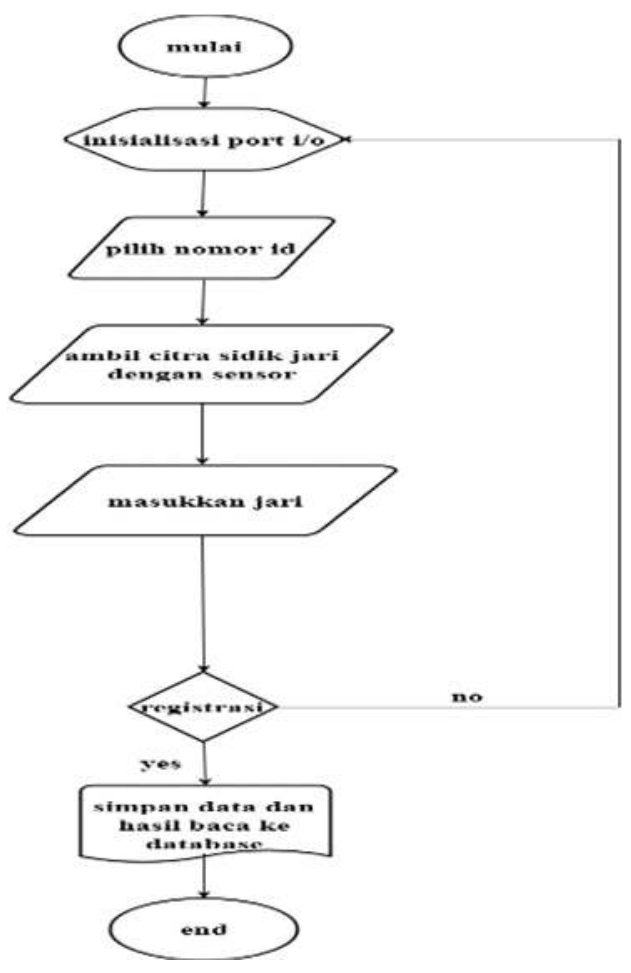

Gambar 7 diagram alir proses verifikasi 


\section{B. Perancangan Mekanik Boks Alat}

Boks adalah sebuah benda yang berbentuk persegi atau persegi panjang dan berfungsi untuk menaruh benda, pada perancangan tulisan ini bagian kanan boks akan disediakan satu tombol yang berfungsi sebagai tombol registrasi, dan tombol yang lainya berfungsi sebagai tombol verifikasi. Lalu pada bagian depan akan disediakan tombol Pushbutton yang berfungsi sebagai input untuk memilih nomor identitas sebelum melakukan pembacaan sidik jari untuk pertama kali, kemudian di dalam boks ini juga telah disediakan sebuah tampilan lcd yang berfungsi sebagai output pada alat ini. Bentuk boks alat ini adalah persegi panjang dengan menggunakan bahan yang terbuat dari akrilik, boks memiliki ukuran panjang $30 \mathrm{~cm}$, lebar $15 \mathrm{~cm}$, dan tinggi $15 \mathrm{~cm}$.

\section{HASIL DAN PEMBAHASAN}

A. Pengukuran Tegangan Rangkaian Catu Daya

Transformator yang digunakan pada pembuatan catu daya ini adalah transformator stepdown 2A. Tegangan AC $220 \mathrm{~V}$ pada sisi primer dan tegangan $\mathrm{AC} 12 \mathrm{~V}$ pada sisi sekunder akan digunakan sebagai tegangan yang akan di searah kan menjadi tegangan keluaran 5 VDC dan 12 VDC.

Dari pengujian dan pengukuran yang telah dilakukan maka diperoleh hasil pengukuran pada tabel berikut :

\begin{tabular}{|l|r|}
\hline Titik Pengukuran & Hasil Pengukuran \\
\hline $\begin{array}{l}\text { Tegangan sisi primer } \\
\text { transformator }\end{array}$ & $219,5 \mathrm{~V}(\mathrm{AC})$ \\
\hline $\begin{array}{l}\text { Tegangan sisi sekunder } \\
\text { transformator }\end{array}$ & $18,7 \mathrm{~V}(\mathrm{AC})$ \\
\hline $\begin{array}{l}\text { Tegangan Output Dioda } \\
\text { Bridge }\end{array}$ & $16 \mathrm{~V}(\mathrm{AC})$ \\
\hline $\begin{array}{l}\text { Tegangan Output } \\
\text { regulator LM7812 }\end{array}$ & $5,06 \mathrm{~V}(\mathrm{DC})$ \\
\hline $\begin{array}{l}\text { Tegangan Output } \\
\text { regulator LM7805 }\end{array}$ & \\
\hline
\end{tabular}

Dari hasil pengujian dan pengukuran pada rangkaian catu daya, dapat di analisis berapa persentase kesalahan antara tegangan keluaran yang diinginkan dengan tegangan keluaran yang diukur

Persentase kesalahan antara tegangan yang diinginkan dengan tegangan yang diukur pada keluaran 5 VDC adalah $=-0,012 \%$

Persentase kesalahan antara tegangan yang diinginkan dengan tegangan yang diukur pada Output 12 VDC adalah 0, 0075\%

Penyimpangan yang terjadi yaitu pada keluaran regulator 7805 sebesar $-0,012 \%$.

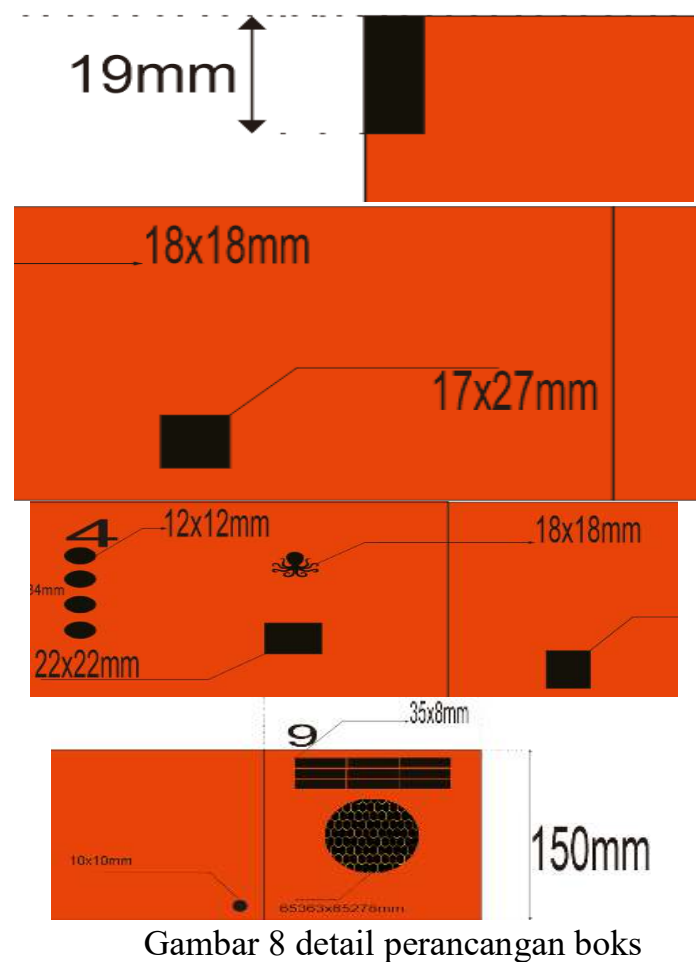

Penyimpangan tersebut masih dalam toleransi, karena range output pada IC LM 7805 adalah 4,8 $-5,2$ VDC. Berdasarkan dari kondisi pengukuran dan analisa di atas, maka rangkaian catu daya untuk keluaran 5 VDC telah dapat bekerja dengan baik sedangkan penyimpangan pada regulator 7812 masih dalam toleransi karena range output pada IC LM $7812 \pm 4 \%$ atau 11,5 - 12,5 VDC . Berdasarkan dari kondisi pengukuran dan analisa di atas, maka rangkaian catu daya untuk keluaran +12 VDC telah dapat bekerja dengan baik.

B. Pengujian Rangkaian Secara Keseluruhan

Pengujian ini dilakukan untuk mengetahui apakah sistem dapat bekerja dengan baik. Untuk melakukan pengujian ini yaitu dengan menjalankan sistem secara keseluruhan mulai dari power supply, mikrokontroller atmega328, fingerprints, pushbutton dan LCD

Terlebih dahulu alat dihubungkan dengan sumber PLN 220VAC lalu pindahkan posisi saklar yang berada di bawah LCD ke posisi 1 atau ON, ketika alat sudah siap beroperasi maka alat akan menampilkan nama alat, nama penulis, dan waktu ketika alat dihidupkan setelah itu tekan tombol enroll untuk meregistrasi pengguna kemudian pilih nomor list pengguna ke berapa sisik jari akan didaftarkan, letakkan jari yang akan digunakan untuk melakukan proses absensi pada sensor fingerprints selanjutnya masukkan sekali lagi untuk verifikasi 
Berdasarkan basil pengujian sistem keseluruhan di atas, kita dapat melihat kondisi tiap - tiap komponen di tiap prosesnya. Yang pertama kita memastikan catu daya mendapat tegangan dari keluaran PLN 220 Vac. Catu daya digunakan sebagai sumber tegangan untuk seluruh rangkaian yang ada. Pada alat ini kita menggunakan catu daya bernilai sebesar 12 Vdc menuju mikrokontroller atmega328, dan 5 Vdc menuju sensor fingerprints

Pada saat sistem dalam keadaan inisialisasi, LCD akan menampilkan, nama, nim, judul tulisan dari penulis, dan waktu ketika sistem dihidupkan. Dan Sistem Absensi akan aktif setelah di tekan tombol start, maka kita akan melakukan beberapa proses untuk bisa melalukan proses pengambilan resensi sesuai dengan perancangan.

Pertama LCD akan menampilkan nama alat dan nama penulis setelah muncul jam, tanggal, bulan dan tahun kita harus melakukan registrasi terlebih dahulu dengan cara menekan tombol OK lalu kita pilih nomor list pengguna yang ada di sistem dari 1 sampai 20. Kemudian tekan tombol OK lagi lalu letakkan sidik jari ke sensor kemudian lepaskan dan letakkan sekali lagi untuk memverifikasi bahwa jari yang kita letakkan ke sensor itu adalah jari yang akan kita pakai untuk melakukan proses pengambilan resensi.

Berdasarkan pengujian sistem keseluruhan ini, bisa disimpulkan bahwa tiap-tiap komponen pada tulisan ini telah berjalan dengan yang diinginkan namun masih terdapat kelemahan pada sensor yang digunakan oleh alat pada pembuatan tulisan ini yang mana waktu untuk membaca masih terbilang cukup lama yaitu 0,5 detik untuk pembacaan tiap-tiap jari yang ingin didaftarkan ataupun diverifikasikan. Sedangkan waktu baca yang diinginkan yaitu 0,3 detik.

\section{KESIMPULAN}

Dari perancangan, pembuatan, hasil dan pengujian perangkat keras, serta perangkat lunak pada tulisan ini, maka dapat diperoleh kesimpulan berikut :

Sistem absensi Elektronik Berbasis Mikrokontroller Atmega328 sebagai pusat kontrol utama dan menggunakan bahasa $\mathrm{c}$ untuk pemrogramannya dengan menggunakan tegangan masukan yang bernilai 12 volt de sehingga sistem dapat bekerja dengan baik.

Sistem absensi elektronik berbasis mikrokontroller atmega328 dapat bekerja sebagai pengganti sistem absensi konvensional

Proses resensi hanya dapat dilakukan setelah pengguna melakukan proses registrasi.

\section{DAFTAR PUSTAKA}

[1].mesinabsensi.co,id. 2013. Pengertian dan macam-macam mesin absensi(online) diakses pada 5 Januari 2018

[2].Panggabean. 2013. Pengaruh Program Aplikasi Absensi Terhadap Kinerja Karyawan Pada PT. PLN (online). Diakses: 6 Desember 2017.

[3].Julius. 1991. Manajemen personalia (online). Diakses pada 7 Januari 2018

[4].Faisal, Ahmad. 2006. Mesin Absensi Sidik Jari (online). diakses pada 18 Januari 2018

[5]. Arduino.cc(online). diakses pada 19 Januari 2018

[6].Badan Pengkajian dan Penerapan Teknologi. 2010. Seminnar kedahsyatan sidik jari (online). diakses pada 17 Januari 2018

\section{Biodata Penulis}

Subandi Saputra, lahir di Kotohilalang 20, September 1994. Jurusan Teknik Elektro Program Studi Teknik Elektro Industri di Universitas Negeri Padang tahun 2013.

Aswardi, lahir di Kubang Putih 21 Februari 1959. Lulusan ITB tahun 1999 bidang kajian yang didalami mesin listrik dan elektronika daya menjadi Dosen jurusan Teknik Eletro Program Studi Teknik Elektro Industri di Universitas Negeri Padang tahun 1985. 